\title{
Window Shopping Assisted by Geoenzo to Increase Students' Conceptual Understanding in Mathematics to Learning Interest
}

\author{
Fredi Ganda Putra ${ }^{1}$, Dyan Revianto ${ }^{2}$, Rizki Wahyu Yunian Putra ${ }^{3}$, Santi Widyawati ${ }^{4}$ \\ 1,2,3 Pendidikan Matematika, UIN Raden Intan Lampung \\ ${ }^{4}$ Pendidikan Matematika, Universitas Nahdlatul Ulama Lampung \\ *fredigpsw@radenintan.ac.id
}

\begin{abstract}
Abstrak
Tujuan penelitian ini adalah untuk mengetahui: 1) pengaruh model pembelajaran Windows Shopping berbantuan Geoenzo terhadap kemampuan konsep matematis; 2) pengaruh minat belajar terhadap kemampuan konsep matematis; dan 3) interaksi antara $\mathrm{h}$ model pembelajaran Windows Shopping berbantuan Geoenzo dengan minat belajar terhadap kemampuan konsep matematis. Jenis penelitian yang digunakan untuk mencapai tujuan penelitian adalah eksperimen semu. Teknik pengumpulan data yang digunakan adalah tes, dokumentasi dan angket (kuisioner), yang selanjutnya akan di uji menggunakan uji analysis of varians (anova). Hasil penelitian menunjukkan bahwa: 1) terdapat pengaruh antara model Windows Shopping terhadap kemampuan pemahaman konsep matematis; 2) Kategori minat belajar (tinggi, sedang, rendah) peserta didik tidak berpengaruh terhadap kemampuan pemahaman konsep matematisnya; 3) tidak ditemukan interaksi antara model pembelajara Windows Shopping berbantuan software geoenzo dengan minat belajar terhadap kemampuan pemahaman konsep matematis peserta didik.

Kata kunci: Minat, Windows Shopping, Pemahaman Konsep, Geoenzo.
\end{abstract}

\begin{abstract}
The purposes of this research were determining (1) the effect of the Windows Shopping learning model assisted by Geoenzo on mathematical concepts understanding ability, 2) the influence of learning interest on mathematical concepts understanding ability, and 3) the interaction between Window Shopping learning model assisted by Geoenzo and learning interest towards mathematical concepts understanding ability. The sample in this study was selected using a randomized class technique, so that classes VIIA (23 students) and VIIB (24 students) in private Madrasah Tsanawiyah in the Kedondong city at 2020/2021 as a samples. This research was quasi-experimental design. The data collecting techniques used were tests, documentation, and questionnaires, which were then tested using the analysis of variance (ANOVA) test. The results showed that (1) there was an influence between the Window Shopping model assisted by Geoenzo on mathematical concepts understanding ability, (2) students' category of learning interest (high, medium, and low) did not affect the mathematical concepts understanding ability, and (3) there was no interaction between the Window Shopping learning model assisted by geoenzo and learning interest towards students' mathematical concepts understanding ability.
\end{abstract}

Keywords: Interest, Window Shopping, Concepts Understanding, Geoenzo.

Received: Desember 09, 2020 / Accepted: January 10, 2021/ Published Online: January 28, 2021 
e-ISSN : 2656-7245 Window Shopping Assisted by Geoenzo to Increase Students' Conceptual Understanding in Mathematics to Learning Interest

\section{INTRODUCTION}

Indonesia is an archipelago country (Kusmana \& Hikmat, 2015), where equal development is challenging to achieve. This situation affects the equal distribution of education quality in a different region, so Indonesia's quality of education is low (Friantini \& Winata, 2019). The low education quality makes students unable to develop their potential. This problem contradicts the objectives of mathematics learning in Junior High School/Madrasah Tsanawiyah, which is to understand the concept of mathematics well to be useful for equal distribution of national development (Antika et al., 2019).

Obstructed potential development has negative impacts on mathematical abilities. It can be seen from the second-semester test scores in one of the private Madrasah Tsanawiyah in the Kedondong city at 2020/2021, where students' mathematics passing rate is only $38.70 \%$. The concept understand ability is directly proportional to the learning outcomes (Murniawati, 2015; Rahmawati \& Kusuma, 2019; Sappaile, 2019). Therefore, it can be interpreted that concept understanding is an important part of mathematics learning process in the classroom. Students' poor mathematical concept understanding is influenced by choice of learning models in the classroom (Hadi \& Kasum, 2015) and less meaningful learning (Jeheman et al., 2019). One of the learning models that can be used is the learning model Window Shopping.

Implementing the Window Shopping learning model is expected to improve students' mathematical concept understanding. This learning model can create conducive class atmosphere (Arini et al., 2019; Nofita et al., 2020) and can create a pleasant learning atmosphere so that students could understand the learning material (Arini et al., 2019; Kusuma Negara, 2020; Nofita et al., 2020; Wirana et al., 2020). Window Shopping uses a constructivist learning approach. This approach is student-centered which emphasizes the importance of individuals knowledge building and understanding through teachers' guidance (Paradesa, 2015). The Window Shopping type cooperative learning model (shopping for works) is expected to strengthen cooperation, courage, democracy, curiosity, and interaction to improve the concept of understanding.

The Window Shopping learning model can be combined with the Geoenzo software. Geoenzo is software that helps teachers display two-dimensional images and shapes so that the delivery of the concept can be easily understood by students (Syamsuddin et al., 2020). This software can improve students' visual-spatial intelligence in the cube and block learning material (Albi, 2018). 
Another essential factor in determining students' success in learning mathematics is the learning interest. Interest is a feeling of liking or feeling attracted to something without others' coercion. Interest will grow by selecting something. Several studies have also indicated that learning interest aligns with learning outcomes (Fimansyah, 2015; Setyowati \& Widana, 2016; Binuni et al., 2017; Sirait, 2016). The effect of learning interest on concept understanding ability is interesting to see.

Several researchers have seen the impact of implementing the Window Shopping learning model on geography learning outcomes (Wirana et al., 2020) and the mathematical connection ability (Hajar, 2018). In this research, the novelty lies in the interaction between the Window Shopping learning model assisted by Geoenzo software and the learning interest in understanding the mathematical concepts.

\section{METHOD}

Research methods are generally defined as a scientific way of obtaining data with specific purposes and uses. The experimental research method used was a quasi-experimental design. The populations of this research was students of class VIII Madrasah Tsanawiyah private Kedondong City for the academic year 2020/2021 totaling 215 students. The research design in Table 1.

Table 1. Research Design

\begin{tabular}{lrcc}
\hline \multicolumn{2}{c}{ Learning Model $\left(\mathrm{A}_{\mathrm{i}}\right)$} & \multicolumn{3}{c}{ Learning Interest $\left(\mathrm{B}_{\mathrm{j}}\right)$} \\
\cline { 2 - 4 } & High $\left(\mathrm{B}_{1}\right)$ & Moderate $\left(\mathrm{B}_{2}\right)$ & Low $\left(\mathrm{B}_{3}\right)$ \\
\hline $\begin{array}{l}\text { Window Shopping } \\
\text { assisted by Geoenzo }\left(\mathrm{A}_{1}\right)\end{array}$ & $\left(\mathrm{A}_{1} \mathrm{~B}_{1}\right)$ & $\left(\mathrm{A}_{1} \mathrm{~B}_{2}\right)$ & $\left(\mathrm{A}_{1} \mathrm{~B}_{3}\right)$ \\
\hline Direct $\left(\mathrm{A}_{2}\right)$ & $\left(\mathrm{A}_{2} \mathrm{~B}_{1}\right)$ & $\left(\mathrm{A}_{2} \mathrm{~B}_{2}\right)$ & $\left(\mathrm{A}_{2} \mathrm{~B}_{3}\right)$ \\
\hline
\end{tabular}

In this research, the data collecting instruments used were a learning interest questionnaire and a concept understanding test. The instruments used had passed the validity test, reliability test, difficulty level test, and discrimination index. The data analysis used in this research was the two-way ANOVA test. The following is the flowchart of this research:

Below on Figure 1, the researchers divided the samples into an experimental class and a control class. The research sample was selected using a randomized class method. The experimental class was taught using the Window Shopping model assisted by geoenzo 
e-ISSN : 2656-7245 Window Shopping Assisted by Geoenzo to Increase Students' Conceptual Understanding in Mathematics to Learning Interest software and the control class was conducted using a conventional approach. Students' learning interest was divided into three groups, namely high, medium, and low.

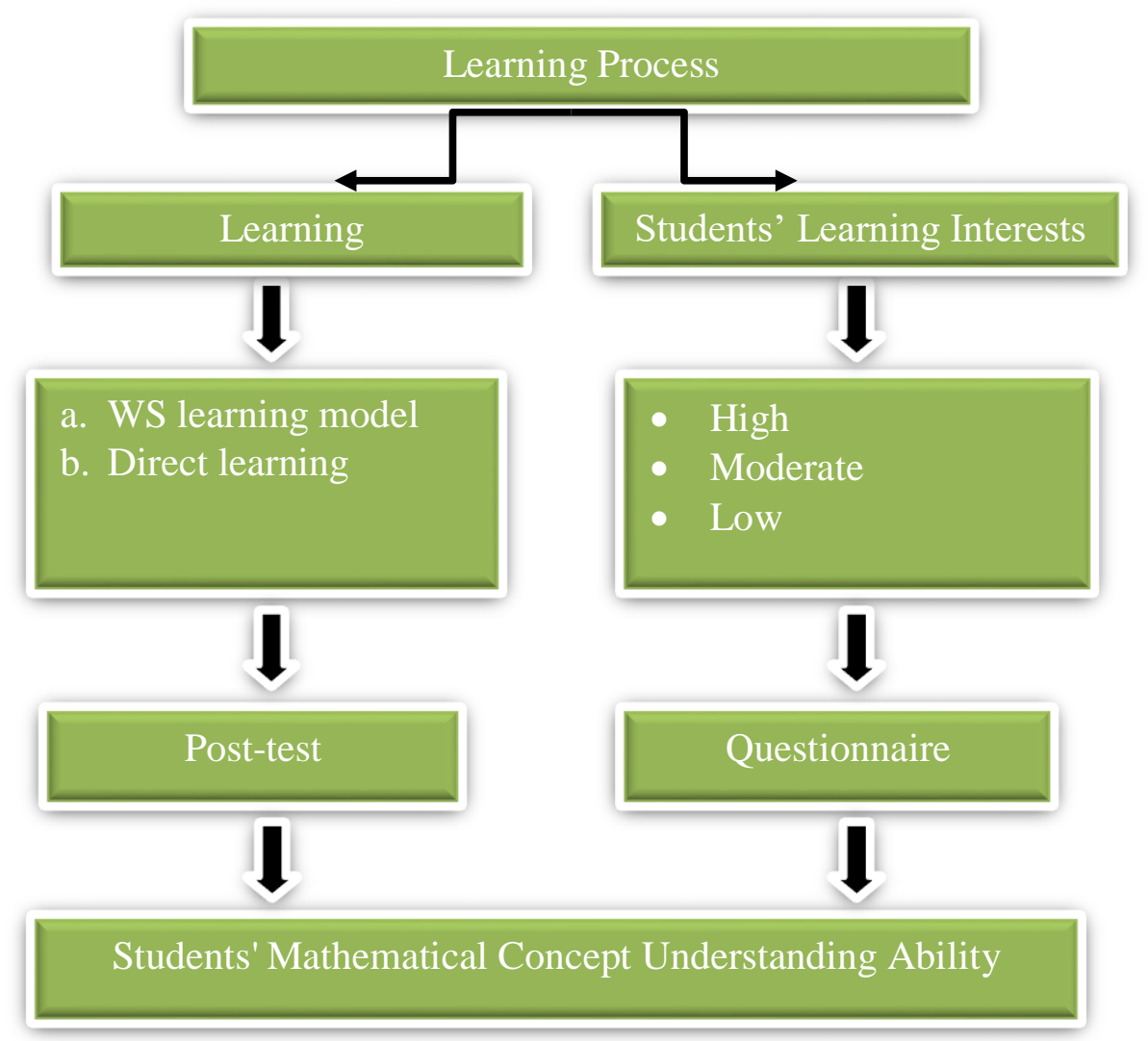

Figure 1. Research Flowchart

\section{RESULTS}

The data obtained were students' learning outcomes related to the students' mathematical concept understanding ability assisted by Geoenzo software. The researchers collected the data after the students had completed the learning and test. The scores obtained by the experimental class 1 , experiment class 2 , and the control class were collected to determine the highest score $\left(\mathrm{X}_{\max }\right)$ and the lowest score. Then, the central tendency was determined, including mean $(\bar{X})$, median $\left(M_{e}\right)$, mode $\left(M_{o}\right)$, and the size of the group variance, including range (R) and standard deviation (s), which can be summarized in Table 2.

Table 2. The Results of Conceptual Understanding Test

\begin{tabular}{cccccc}
\hline \multirow{2}{*}{ Classes } & \multirow{2}{*}{$X_{\max }$} & $X_{\min }$ & \multicolumn{3}{c}{ Central Tendency Measurement } \\
\cline { 4 - 6 } & & $\bar{x}$ & $M_{o}$ & $M_{e}$ \\
\hline Experimental 1 & 100 & 75 & 88.29 & 96.43 & 89.29 \\
\hline Experimental 2 & 100 & 75 & 89.22 & 85.71 & 92.86 \\
\hline Control & 100 & 64.29 & 80.14 & 75 & 78.57 \\
\hline
\end{tabular}


Fredi Ganda Putra, Dyan Revianto, Rizki Wahyu Yunian Putra, Santi Widyawati e-ISSN : 2656-7245

The questionnaire had been distributed to the students, both in the experimental class and the control class. The results are shown in Table 3.

Table 3. The Results of Learning Interest Questionnaire

\begin{tabular}{lccc}
\hline \multirow{2}{*}{ Classes } & \multicolumn{3}{c}{ Learning Interest } \\
\cline { 2 - 4 } & High & Moderate & Low \\
\hline Experimental 1 & 4 & 20 & 1 \\
\hline Experimental 2 & 4 & 25 & 4 \\
\hline Control & 4 & 16 & 5 \\
\hline
\end{tabular}

The data for calculating the normality test for each class can be seen in Table 4 . The results of the normality test are presented in Table 4.

Table 4. The Summary of Data Normality Test Results

\begin{tabular}{cllll}
\hline No. & \multicolumn{1}{c}{ Classes } & $\boldsymbol{L}_{\text {observed }}$ & $\boldsymbol{L}_{\text {critical }}$ & \multicolumn{1}{c}{ Results } \\
\hline 1 & Experimental 1 $\left(a_{1}\right)$ & 0.1136 & 0.173 & Normal Distribution \\
\hline 2 & Experimental 2 $\left(a_{2}\right)$, & 0.1514 & 0.1610 & Normal Distribution \\
\hline 3 & Control $\left(a_{3}\right)$ & 0.1477 & 0.173 & Normal Distribution \\
\hline 4 & High $\left(b_{1}\right)$ & 0.1594 & 0.242 & Normal Distribution \\
\hline 5 & Medium $\left(b_{2}\right)$ & 0.0964 & 0.113 & Normal Distribution \\
\hline 6 & Low $\left(b_{3}\right)$ & 0.0940 & 0.258 & Normal Distribution \\
\hline
\end{tabular}

Based on the results of the data normality test at a 5\% significance level, the value of $\mathrm{L}_{\text {observed }}$ was lower that $\mathrm{L}_{\text {critical. }}$ Thus, the null hypothesis for each group was accepted. Therefore, it can be concluded that the data in each group came from normally distributed populations. Furthermore, the homogeneity test was carried out using Bartllet's test with a significance level of $5 \%$. The results can be seen in Table 5.

Table 5. The Summary of the Homogeneity Test

\begin{tabular}{ccccc}
\hline No. & Groups & $L_{\text {observed }}$ & $L_{\text {critical }}$ & Results \\
\hline 1 & $a_{1}, a_{2}$, and $a_{3}$ & 3,9896 & 5,991 & $\mathrm{H}_{0}$ is accepted \\
\hline 2 & $b_{1}, b_{2}$, and $b_{3}$ & 2,3058 & 5,991 & $\mathrm{H}_{0}$ is accepted \\
\hline
\end{tabular}

Based on Table 5, it can be concluded that the sample comes from a homogeneous population. The following is the results of the two-way analysis of variance: 
e-ISSN : 2656-7245 Window Shopping Assisted by Geoenzo to Increase Students' Conceptual Understanding in Mathematics to Learning Interest

Table 6. Two-Way Analysis of Variance

\begin{tabular}{ccccccc}
\hline \multicolumn{7}{c}{ Two Way Anava Table } \\
\hline SK & JK & df & RK & F $_{\text {observed }}$ & F $_{\text {critical }}$ & Conclusion \\
\hline Model & 187,529 & 2 & 93,764 & 6,352 & 3,120 & $\mathrm{H}_{0}$ is Rejected \\
\hline Lerning interest & $2,825,653$ & 2 & 1412,826 & 2,715 & 3,120 & $\mathrm{H}_{0}$ is Accepted \\
\hline Interaction & $-14,863,195$ & 4 & $-3715,799$ & $-251,734$ & 2,495 & $\mathrm{H}_{0}$ is Accepted \\
\hline Error & $1,092,299$ & 74 & 14,761 & & \multicolumn{1}{c}{} \\
\hline Total & $-10,757,714$ & 82 & \multicolumn{7}{c}{} \\
\hline
\end{tabular}

Based on the results of statistical data analysis, very significant results were obtained between $\mathrm{F}_{\text {observed }}$ and $\mathrm{F}_{\text {critical. }}$. Therefore, there was an influence of the Window Shopping learning model assisted by Geoenzo and conventional learning on the mathematical concepts understanding ability. Further analysis using Scheffe method found a very significant difference between the Window Shopping learning model assisted by Geoenzo and conventional learning on students' mathematical concept understanding ability, which means that the application of the window shopping learning model assisted by Geoenzo provides better concept understanding results than the direct learning model.

Based on the first row of Table 6, it can be concluded that there was an influence of the Window Shopping learning model on the mathematical concepts understanding ability $\left(\mathrm{H}_{0}\right.$ is rejected). The results were in line with the Window Shopping learning model assisted by Geoenzo concept, where the learning model can create an active classroom atmosphere (Arini et al., 2019; Nofita et al., 2020) and can help students understand the learning material (Wirana et al., 2020).

Next, in the second line of Table 6 about the learning interest, it can be concluded that the level of students' learning interest was not influence students' conceptual understanding. The category of learning interest has no effect on students' mathematical concepts understanding ability because, during learning, students in all categories of learning interest were enthusiastic. It is in line with previous research, which states that learning interest does not significantly affect students' learning outcomes due to the number of subjects and students in the class (Fimansyah, 2015). In the third row of Table 6 the interaction section, it can be concluded that there was no interaction between the Window Shopping learning model assisted by geoenzo software and learning interest towards students' mathematical concepts understanding ability. This means that the learning model used and the category of interest in learning have no difference in the results of the students' ability to understand mathematical concepts. 
Fredi Ganda Putra, Dyan Revianto, Rizki Wahyu Yunian Putra, Santi Widyawati e-ISSN : 2656-7245

\section{CONCLUSION}

Based on data analysis and hypothesis testing, the following conclusions are drawn. First, there was an effect of the Window Shopping learning model assisted by Geoenzo on students' mathematical concepts understanding ability. Based on the post-ANOVA test, Students' mathematical concepts understanding ability using the Window Shopping learning model assisted by GeoEnzo was the same as students who use the Window Shopping learning model assisted by Geoenzo. However, both models produced better mathematical concept understanding ability compared to the conventional learning model. Second, there was no influence between students who have learning interest (high, medium, and low) on their mathematical concept understanding ability. Third, there was no interaction between the Window Shopping learning model assisted by Geoenzo and learning interest towards students' mathematical concepts understanding ability.

\section{SUGGESTION}

The use of window shopping learning model assisted by geoenzo software can be used as a learning solution in the classroom to improve students' conceptual understanding. For the next researchers, can use this model as a solution to improve other mathematical abilities.

\section{REFERENCES}

Albi, N. W. (2018). Penerapan Software Geoenzo 3.7 Untuk Meningkatkan Kecerdasan Visual-Spasial Siswa Pada Materi Kubus dan Balok Kelas VIII di SMP Negeri 3 Padangsidimpuan. Skripsi, IAIN Padangsidimpuan. Diambil dari http://etd.iainpadangsidimpuan.ac.id/2249/1/14\%20202\%2000103.pdf

Antika, M. S., Andriani, L., \& Revita, R. (2019). Pengaruh Penerapan Model Pembelajaran Kooperatif Tipe Think-Pair-Square terhadap Kemampuan Pemahaman Konsep Matematis Ditinjau dari Kemampuan Awal Matematika Siswa SMP. JURING (Journal for Research in Mathematics Learning), 2(2), 118-129. https://doi.org/10.24014/juring.v2i2.7553

Arini, I., Simal, R., \& Pattiruhu, D. O. (2019). Perbedaan Hasil Belajar Siswa Kelas XI SMA Negeri 1 Ambon Dengan Penerapan Model Window Shopping Dan Examples Non Examples Pada Konsep Sistem Koordinasi. Science Map Journal, 1(1), 23-28. https://doi.org/10.30598/jmsvollissue1pp23-28

Binuni, J., Kaunang, E. S. N., \& Sumampouw, H. M. (2017). Hubungan Minat Terhadap Hasil Belajar Siswa Pada Mata Pelajaran Ipa Biologi Sma Negeri 2 Tondano. JSME (Jurnal Sains Matematika Dan Edukasi), 5(2), 184-187.

Fimansyah, D. (2015). Pengaruh Strategi pembelajaran dan minat belajar terhadap hasil belajar matematika. Judika (Jurnal Pendidikan UNSIKA), 3(1). 34-44. 
e-ISSN : 2656-7245 Window Shopping Assisted by Geoenzo to Increase Students' Conceptual Understanding in Mathematics to Learning Interest

Friantini, R. N., \& Winata, R. (2019). Analisis Minat Belajar pada Pembelajaran Matematika. JPMI (Jurnal Pendidikan Matematika Indonesia), 4(1), 6-11. https://doi.org/10.26737/jpmi.v4i1.870

Hadi, S., \& Kasum, M. U. (2015). Pemahaman konsep matematis siswa SMP melalui penerapan model pembelajaran kooperatif tipe memeriksa berpasangan (Pair Checks). Edu-Mat: Jurnal Pendidikan Matematika, 3(1). 59-66.

Hajar, S. (2018). Penerapan Model Pembelajaran Window Shopping untuk Meningkatkan Kemampuan Koneksi Matematis dan Minat Belajar Siswa [PhD Thesis]. UIN Sunan Gunung Djati Bandung.

Jeheman, A. A., Gunur, B., \& Jelatu, S. (2019). Pengaruh Pendekatan Matematika Realistik terhadap Pemahaman konsep matematis Siswa. Mosharafa: Jurnal Pendidikan Matematika, 8(2), 191-202.

Kusmana, C., \& Hikmat, A. (2015). Keanekaragaman hayati flora di Indonesia. Journal of Natural Resources and Environmental Management, 5(2), 187-187.

Kusuma Negara, I. S. (2020). Peningkatan Minat Belajar Mahasiswa Dengan Menggunakan Metode Pembelajaran Kooperatif Window Shopping Pada Mata Kuliah Ekonomi Pembangunan. Hospitality, 9(1), 105-110.

Murniawati, N. W. S. (2015). Hubungan Antara Pemahaman Konsep dan Motivasi Belajar dengan Hasil Belajar Siswa. Skripsi, 1(421411059).

Nofita, N., Zulkifi, Z., \& Rita, K. (2020). Meningkatan Kemampuan Berbicara Anak usia 4-5 Tahun Melalui Model Pembelajaran Window Shopping di TK Ibnu Sina Kota Pekanbaru. Jurnal Review Pendidikan Dan Pengajaran, 3(1), 108-114.

Paradesa, R. (2015). Kemampuan berpikir kritis matematis mahasiswa melalui pendekatan konstruktivisme pada matakuliah matematika keuangan. Jurnal Pendidikan Matematika RAFA, 1(2), 306-325.

Rahmawati, N. K., \& Kusuma, A. P. (2019). Hubungan Pemahaman Konsep Aritmatika Sosial Dengan Hasil Belajar IPS Materi PPH. Buana Matematika: Jurnal Ilmiah Matematika Dan Pendidikan Matematika, 9(1), 1-6.

Sappaile, N. (2019). Hubungan Pemahaman Konsep Perbandingan dengan Hasil Belajar Kimia Materi Stoikiometri. Jurnal Ilmu Pendidikan (JIP) STKIP Kusuma Negara, 10(2), 58-71.

Setyowati, D., \& Widana, I. W. (2016). Pengaruh minat, kepercayaan diri, dan kreativitas belajar terhadap hasil belajar matematika. Emasains, 5(1), 66-72.

Sirait, E. D. (2016). Pengaruh Minat Belajar Terhadap Prestasi Belajar Matematika. Formatif: $\begin{array}{llll}\text { Jurnal Ilmiah } & \text { PIPA, }\end{array}$ https://doi.org/10.30998/formatif.v6i1.750 
Syamsuddin, S., Ahmad, H., Hasliana, L., Latif, A., \& Tasni, N. (2020). PKM - Peningkatan Keterampilan Guru Matematika SMK Kabupaten Majene dalam Penggunaan Geoenzo sebagai Media Pembelajaran Matematika. Jurnal Cemerlang: Pengabdian Pada Masyarakat, 3(1), 60-73.

Wirana, R., Abdi, A. W., \& Ridha Maulidian, M. O. (2020). Penerapan Model Pembelajaran Window Shopping Berbantuan Multimedia Untuk Meningkatkan Hasil Belajar Geografi Siswa Kelas XI SMA Negeri 16 Banda Aceh. Jurnal Ilmiah Mahasiswa Pendidikan Geografi FKIP Unsyiah, 5(4), 295-303. 